\title{
Cinema e transformação social: o Instituto de Cinematografia de Santa Fé (1956-1962) *
}

\author{
Mônica Cristina Araujo Lima**
}

Resumo: Este artigo discute o processo de implantação do Instituto de Cinematografia de Santa Fé, na Universidade do Litoral, Argentina, em um momento de crise da cinematografia do continente latino-americano. Identifica a influência do Centro Experimental de Cinematografia de Roma, onde havia estudado seu diretor e fundador, Fernando Birri, e da Escola de documentaristas ingleses, dirigida por John Grierson. Demonstra a criatividade de seus integrantes para adaptar propostas cinematográficas internacionais para as sociedades latino-americanas e relacioná-las às propostas culturais da esquerda dos anos 50. Identifica, ainda, a singularidade de seu método para a produção cinematográfica, e a relação do Instituto com a comunidade local.

Palavras-chave: América Latina - Cinema - História

O Instituto de Cinematografia de Santa Fé, também conhecido como Escola Documental de Santa Fé, foi fundado no dia 19 de dezembro de 1956 dentro da Universidade Nacional do Litoral. Segundo Fernando Birri, foram decisivas para a instalação da escola a atuação progressista do reitor, professor Dr. Josué Gollan, e da diretora do Instituto Social, professora Dra. Angela Romero Vera. ${ }^{1}$

É considerado a primeira escola de cinema da América Latina. Desde sua fundação, o Instituto demonstrou um caráter singular na forma de produção cinematográfica: novo método de ensino, forma diferenciada de seleção dos temas, preocupação com conteúdo social e crítico e aberto a alunos de todos os departamentos da universidade e à comunidade de Santa Fé.

O Instituto de Cinematografia de Santa Fé atravessou conjunturas nacionais de autoritarismo e abertura política. Fundado no governo ditatorial de Pedro Aramburu (1955-1958), teve seu momento de maior produtividade no governo eleito democraticamente de Arturo Frondizi (1958-1962).

Ao retornar da Itália, em 1954, após cursar o Centro Experimental de Cinematografia de Roma, Birri acompanhou a transição política na Argentina e fez parte do grupo de discussão do plano de governo de Frondizi. Organizou, no Instituto Social, em Santa Fé, um seminário de cinema. Entretanto, a relação de Birri com a 
Universidade do Litoral era mais antiga. Ele havia estudado anteriormente no Instituto Social e dirigido, em 1947, o primeiro grupo de teatro amador da Universidade.

O diretor propunha-se "utilizar el cine al servicio de la Universidad y la Universidad al servicio de la educación popular, de una toma de conciencia cada vez más responsable" (Avellar, 1995, p.47). Esta parceria era inédita na América Latina e resultou no Instituto de Cinematografia de Santa Fé.

A institucionalização da escola ocorreu em paralelo às discussões sobre a necessidade de centros de formação universitária na área cinematográfica. À época, discutia-se a possibilidade da fundação de uma escola nacional de cinema, mas Fernando Birri achou melhor construir um instituto a partir de uma alternativa mais pragmática e realista que fugisse da eterna burocracia latino-americana.

Propôs, então, começar com um seminário de cinematografia, complementado com aulas práticas. Entre os seminaristas estavam jovens escritores, escultores e músicos da cidade, sócios dos cineclubes, integrantes dos teatros independentes e, principalmente, estudantes universitários e secundaristas, assistentes sociais e professores. O primeiro seminário durou quatro dias e foi realizado na Faculdade de Direito da Universidade, com a participação de 130 alunos. Segundo Birri:

Los cursos se dictaron en las aulas de la Facultad de Derecho; por la tarde, los teóricos, según el programa desarrollado por Luigi Chiarini en el Centro Experimentale di Cinematografía de Roma (por dos razones: trataba, de este modo, de transmitir lo que a mi vez había aprendido cuando alumno de aquel Centro; la otra razón consistía en que los nuevos alumnos podían contar, para fijar y rumiar los conceptos vertidos durante el cursillo, com el libro "Il Film Nei Problemi Dell'Arte", del mismo Chiarini ... (Birri, 1964, p.18)

O grupo propôs um método de formação que unisse a teoria e a prática cinematográfica, capaz de ultrapassar o empirismo da indústria cinematográfica e o isolamento do cinema experimental. O objetivo foi realizar filmes a partir do conhecimento da realidade argentina e, em particular, da cidade de Santa Fé. Foi buscar um cinema alternativo aos filmes comerciais, que não tinham nenhuma visão crítica da sociedade, e aos filmes "intelectuais", "de elite" e "evasivos", que não conseguiam chegar ao grande público. Ou seja, foi fazer um cinema com qualidades artísticas que alcançasse um público popular.

Buscou-se uma contraposição ao pragmatismo do cinema comercial produzido na Argentina pelos estúdios e ao hermetismo do cinema experimental. Para eles, o 
cinema de arte e o cinema comercial serviram a uma cultura decadente, burguesa, colonial. Queriam produzir um cinema que, ao mesmo tempo, fosse crítico e original e que conseguisse atingir um grande público. Para isso tinham como objetivo central um projeto que estivesse ligado à realidade nacional e popular argentina.

Para Fernando Birri:

Lo esencial era que ahora todos estábamos llenos de preguntas, no se trataba - y esto había quedado claro desde la primera introducción al tema de esa tarde - de repetir, de copiar sin más ni más una acertada experiencia italiana, pero sí de saber, de probarnos a nosotros mismos hasta dónde era posible una asimilación de toda esa experiencia vital con la cual ha tonificado el arte cinematográfico la actitud neorrealista (que, no me cansaré de repetir, antes que un estilo cinematográfico es una actitud moral). En otras palabras, no se trataba de hacer cine neorrealista en la Argentina pero sí de hacer entender - y sobre todo hacer sentir - hasta qué punto es necesario que el arte cinematográfico, en virtud de sus propios medios expresivos, se afiance en la realidad de las imágenes que caen bajo nuestros ojos, bajo nuestros objetivos, y hasta qué punto ese realismo, la realidad de esas imágenes, no pude dejar de ser la realidad de nuestra misma región, de nuestra misma nación, de los temas y problemas que por ser regionales son también nacionales y en todos los casos urgentemente humanos. (ibidem, p.19)

As formulações do Instituto não se restringiram à área cinematográfica. Tratavam também de uma proposta pedagógica e de mudança social. É o que escreveu Manuel Horacio Giménez, na introdução ao livro de Birri que resume a experiência de Santa Fé:

Pero más que compartirlo como espectador pasivo queremos que quien lo lea encuentre en esta experiencia futura... la lucha por la cultura de los pueblos, que es también la lucha contra las poderosas fuerzas que quieren negar el desarrollo, la elevación y la dignidad del hombre sobre la tierra. (ibidem, p. 5)

Manuel Horacio Giménez identificou na origem da crise no cinema argentino dos estúdios a falta de cultura cinematográfica consolidada, ausência de uma escola nacional de cinema, de revistas com tiragens regulares, livros sobre cinema e cineclubes organizados.

Birri associou a criação do Instituto de Cinematografia à tradição inovadora da Universidade Nacional do Litoral, revelada na própria fundação do Instituto Social em 1928. “Todavía no se hablaba entonces de contorno social, de medios de comunicación 
de masa y muy poco de extensión universitaria" (ibidem, p.24). A idéia, então, era comunicar-se com o povo a partir de um projeto didático:

Buscamos a través de él una nueva forma de comunicación con nuestro pueblo en su dimensión real. Ni regionalismo, ni pintetoresquismo, ni arte de vanguardia. Todo lo que queremos es que los alumnos del Instituto aprendan a ver y a expresar lo visto en forma tal que los espectadores de sus trabajos tengan que mirar y compartir; si además realizan algo bello tanto mejor. (ibidem, p. 25)

A partir do seminário, o grupo resolveu realizar fotodocumentários, método aprendido por Fernando Birri na Itália e que consistia em sair com uma máquina fotográfica e um gravador e registrar a realidade do meio ambiente: entrevistar pessoas, fotografar rostos, lugares, animais, vegetação e os problemas do local onde se vivia, método pouco usual no período.

A primeira Exposição de Fotodocumentários foi inaugurada na Associação de Cronistas Cinematográficos de Buenos Aires, em 30 de janeiro de 1958, com a presença e exposição de Ernesto Sábato. Comentando a exposição na revista Nueva Expresión, em junho de 1958, Jorge Alberto Ferrando, poeta e engenheiro, apontou a existência naquele momento de duas vertentes na arte: a que quer mostrar os "trapos sujos" e a que quer mostrar o "belo". Ferrando dizia que o Instituto buscou rastrear o potencial humano, conhecer o povo, o mesmo povo que teve participação na realização cinematográfica de Tire dié.

Em 27 de setembro de 1958, realizou-se a Exposição de Fotodocumentários dos alunos do Instituto. Nela foram apresentadas, junto com Tire dié, 227 fotografias e 112 pesquisas, organizadas pelos seguintes temas:

1) problemas pedagógicos - Retabillo de Perico (construção de um teatro de marionetes por alunos de uma escola primária);

2) problemas econômicos - Reactivación del puerto de Santa Fe;

3) problemas urbanos - 32 sentados - 17 parados (o transporte);

4) problemas de trabalho - Tanino;

5) problemas técnicos - Impresión de un diario, Fundición de una morsa;

6) difusão artística - Gambarte (um pintor do litoral);

7) poesia do cotidiano - Buenos Días, Santa Fe;

8) educação: Escuela Rural n. 101;

9) esportes - El campito (problemas associativos);

10) vida sindical - La Fratenidad; 
11) problemas científicos - Reducción quirúrgica de luxación congénita de cadera;

12) informação - Vida universitaria;

13) problemas estéticos - La pintura americana y el mural en la obra de López Claro (cine-pintura);

14) turismo: Postales.

Esta exposição baseou-se em fotodocumentários publicados, esporadicamente, nas páginas da revista Cinema Nuevo. Ela refletia a impossibilidade econômica de concretização dos filmes. Para aqueles iniciantes no fazer cinematográfico, o fotodocumentário foi usado como método de descoberta de uma realidade colonial e de rompimento com uma indústria cinematográfica que consideravam alienada. Foi o primeiro passo em busca de uma experiência de libertação da cinematografia argentina e latino-americana.

Fernando Birri confessa ter-se apoiado em Grierson e Zavattini para realizar o projeto da Escola:

Nos apoyamos declaradamente en principios hoy todavía tan válidos como los enunciados, por ejemplo, por Grierson y Zavattini, cada uno a su tiempo. Grierson - fundamentador teórico del concepto documentalístico, conductor práctico de las filmaciones del rigoroso Group 3 en Inglaterra - ya en el año 30 define así al cinematógrafo documental: elaboración creativa de la realidad, sosteniendo su vigencia autónoma porque: 1) Creemos que de la capacidad que el cinematógrafo tiene de mirar alrededor suyo, de observar y seleccionar los acontecimientos de la vida verdadera, se puede obtener una nueva y vital forma de arte. 2) Creemos que el actor natural (o auténtico) y el escenario natural (o auténtico), constituyen la guía mejor para interpretar cinematográficamente el mundo moderno. 3) Creemos que el material y los temas encontrados en el lugar son más bellos (más reales en sentido filosófico) que todo lo que nace de la representación. El documental puede profundizar la realidad y obtener de ella resultados que ni la maquinosidad de los sets ni la exquisita declamación de los actores prefabricados se sueña. (ibidem, p.22)

Os documentaristas da Escola de Santa Fé reportaram-se ao mito John Grierson para sustentar sua produção. Apesar de realizador de um único filme como diretor, Drifters $(1928)^{2}$, o escocês foi o ideólogo e principal fundador da escola de documentaristas ingleses. As principais características dessa proposta documental foram resumidas por Da-Rin: 
A questão central, para os artífices da escola inglesa do documentário, estava na utilização do cinema como instrumento para a transformação da sociedade pela via educativa. ... Dramatização, interpretação e intervenção social - estes são os atributos do documentário para seus fundadores. (Da-Rin, 2004, p.93)

As propostas de Grierson vinham sendo discutidas pelos documentaristas norteamericanos do cinema direto e pelos franceses do cinema-verdade. Eles consideravam autoritária a forma de realização e a estética do documentário clássico.

A produtora Drew Associates ${ }^{3}$, formada em torno do repórter fotográfico Robert Drew e do cinegrafista Richard Leacock, foi a mais conhecida representante do cinema direto. Seus realizadores não aceitavam a dramatização, interpretação e intervenção social da produção clássica e acreditavam que a equipe não deveria interferir, de modo algum, no processo de filmagem. Eram, na maioria, jornalistas, nutriam um certo fetichismo pelos novos equipamentos tecnológicos leves e sincrônicos e buscavam a objetividade absoluta.

Os cineastas do cinema-verdade francês eram provenientes da área da sociologia e da etnologia. Consideravam impossível chegar à objetividade absoluta e discutiam a questão da invasão da privacidade na produção do documentário e os problemas éticos que isto poderiam suscitar.

Jean Rouch foi um representante destacado desta tendência. Seu filme Chrônique d'un Été (Crônica de um Verão, 1960), realizado conjuntamente com Edgar Morin, pode ser considerado o protótipo de uma nova configuração do documentário: o modo interativo de representação. Neste filme, o som direto integralmente assumido engendrou consequiências inteiramente distintas daquelas verificadas no modo observacional. Aqui é a palavra que predomina, através da conjugação de diferentes estratégias: monólogos, diálogos, entrevistas dos realizadores com os atores sociais, discussões coletivas envolvendo a crítica aos trechos já filmados e, por fim, autocrítica dos próprios realizadores diante da câmera. Chrônique d'un Été foi uma tentativa de colocar em prática os conceitos desenvolvidos por Morin em seu artigo Por un Noveau Cinéma-Vérité, publicado alguns meses antes. (Da-Rin, 2004, p.149-50)

Os cineastas e professores do Instituto de Cinematografia tinham perfeito conhecimento de todos os debates que aconteciam na época, vários artigos com esses debates eram publicados nas revistas Gente de Cine e Tiempo de Cine. Portanto acreditamos que a opção por Grierson deveu-se à sua proposta pedagógica de transformação social, que se adaptava plenamente ao propósito de conscientização 
popular perseguido pelo Instituto de Cinematografia naquele momento. Grierson escreveu para o grupo de Santa Fé:

Quiero expresarle lo excelente que encontré vuestra exposición en Montevideo. Es un espléndido ejemplo de método de enseñanza y el primero que he visto que contribuya tan simplemente y tan bien al aprendizaje de cómo hacer un film. Ustedes van a la raíz de esta materia captando las imágenes esenciales y forzándoles por medio de los epígrafes a entregar su contenido. Es ésta una contribución notablemente simple pero a la vez profunda. (Birri, 1964, p.30)

Na primeira estruturação da escola ${ }^{4}$, o curso estava organizado para durar três anos. O primeiro ano seria preparatório em todas as fases técnicas da produção, o aluno teria uma visão geral das funções envolvidas na realização de um filme e estaria apto a realizar curtas. Nos dois anos seguintes os alunos teriam uma formação teórica e prática mais aprofundada nas diversas áreas da produção cinematográfica: direção, fotografia, cenografia, roteiro, entre outras.

Com as filmagens de Tire dié (1958) e Los inundados (1962), o diretor e seu grupo criaram uma forma de produção alternativa. Fernando Birri, no programa de apresentação do filme Tire dié, escreveu:

Con esta primera experiencia, producto moral y técnico de la voluntad de hacer de sus alumnos, el Instituto de Cinematografía de la Universidad del Litoral espera: 1) Colaborar en la medida de sus jóvenes fuerzas a la superación de la crisis actual del cine argentino aportando América Latina mismo una problemática nacional, realista y crítica, hasta ahora inédita. 2) Afianzar las bases para una futura industria cinematográfica local, santafesina, de repercusión nacional, en la medida que los alumnos se perfeccionen técnicamente con la periodicidad del aprendizaje cotidiano. La industria cinematográfica argentina ha alcanzado la técnica fotográfica y sonora casi perfecta. Las imperfecciones de fotografía y de sonido de Tire dié se deben a los medios no profesionales con los cuales se ha trabajado forzados por las circunstancias, los cuales, al obligar a una acción y a una opción, han hecho que se prefiera un contenido a una técnica, un sentido imperfecto a una perfección sin sentido; ... Esta acepción es más urgente, la educación popular va entendida como toma de conciencia cada vez más responsable frente a los grandes temas y problemas nacionales hoy y aquí. (ibidem, p.52)

A escola concebida por Birri estava buscando um estilo. Mas o conteúdo viria primeiro: ser útil para a sociedade, ou seja, a técnica acompanhada de sentido. Ela questionava a forma de produção tradicional, o sentido "romântico do artista" e propunha que seus trabalhos fossem realizados por pessoas comuns e coletivamente. 
Em 1957, primeiro ano de funcionamento oficial, as aulas do Instituto se iniciaram em 8 de abril, com 104 alunos inscritos na primeira série preparatória. Os alunos receberam uma introdução geral sobre os problemas estéticos, morais, sociais e técnicos do documentário. Além da iniciação panorâmica, o Instituto de Cinematografia também ofereceu cursos e conferências com especialistas e críticos renomados: La gran misión del filme, José Dominianni; El cine como medio de difusión de conocimientos científicos, Oscar Barrio Olivares; Mi experiencia como autor del libro "El Túnel" (novela y guión), Ernesto Sábato; El libro cinematográfico, su técnica y desarrollo, Rodolfo M. Taboada; Diez Etapas del cine argentino y una más, Carlos Ferreyra; Breve historia crítica del cine argentino, Jaime Potenze; Configuración de la cinematografía contemporánea, su evolución y tendencia actuales, José Agustin Mahieu; Escenografía cinematográfica, Saulo Benavente; La imagen cinematográfica, Simón Feldman; Importancia de la fotografía en el film, Enrique Wallfish; Documentales de Sucksdorff e El cine experimental en Uruguai, Jorge Angel Arteaga. ${ }^{5}$ Além da formação teórica, em parceria com o Cine Clube de Santa Fé, foi organizada também uma programação semanal de filmes com o objetivo de despertar o interesse do público.

Em 1958, o Instituto de Cinematografia organizou-se a partir de três áreas: Seção de Escolástica, Seção de Oficina Experimental e Seção de Produção. A Seção de Escolástica (Teoria) funcionava todos os dias de 16h às 23h. Faziam parte dos cânones clássicos da aprendizagem: planos de estudo, materiais, rigorosa assistência aos alunos, exames periódicos, realização de trabalhos práticos (laboratório fotográfico: revelação, cópia e ampliação). Ela também se ocupava da formação elementar de alunos em dois aspectos fundamentais: teoria geral para realização (direção de documentários e problemas morais, sociais, estéticos e técnicos do cinema) e técnica de fotografia. E também oferecia cursos complementares de sociologia, técnica da pesquisa social e elementos de cultura geral.

A Seção de Oficina Experimental (Prática) apoiou-se no método do fotodocumentário. Abarcava quatro eixos de atividade documentarista: atualidade, documentários didáticos, técnicos ou científicos e dramáticos. Os horários se adequavam às necessidades do trabalho. A atividade desta seção compreendia fundamentalmente quatro etapas clássicas do trabalho do documentarista: a atualidade, que se referia a um momento fugaz, porém ponderável a partir do ponto de vista humano; a didática, que considerava a utilização para fins pedagógicos; a técnica ou científica, que buscava a constatação de um processo ou fenômeno; a dramática, onde se 
organizava uma história, permitindo uma livre elaboração pessoal.

A Seção de Produção (Realização) tinha como objetivo elaborar um produto determinado de acordo com as exigências de qualidade do cinema profissional.

Havia, ainda, palestras ministradas por intelectuais e escritores que visitavam a escola: o escritor Francisco Ayala; o crítico de cinema, teatro e diretor da revista Talía, Emilio Stevanovich; o crítico de cinema do jornal La Nación, Ernesto Schoo; e o poeta cubano Nicolás Guillén.

Em 1959 foram instituídas novas disciplinas na grade curricular. Foi um passo importante rumo ao organograma mais complexo dos cursos. Segundo Fernando Birri, o organograma de 1959 corresponde à etapa intermediária, experimental (18 cátedras, 3 cursos), entre o primeiro de 1958 - Escolástica, Oficina Experimental, Produção - e sua definitiva racionalização no Organograma de 1960 (Birri, 1964, p.185).

A equipe técnica, em 1959, foi composta por um diretor, um coordenador docente, 15 professores, um regente, um chefe geral de oficina experimental, um ajudante técnico, um bibliotecário, quatro encarregados de seção, dois preceptores, um auxiliar administrativo, um coordenador, um mensageiro e um motorista. A biblioteca reunia 200 livros sobre a área cinematográfica e 1500 fotografias provenientes dos trabalhos de fotodocumentários dos alunos.

Em maio de 1959, Birri viajou para o Festival de Cannes, na França, como membro oficial da delegação Argentina. Representou o Instituto de Cinematografia, no II Congresso Internacional das Escolas de Cinema e TV em Roma. Também foi convidado para falar da experiência do Instituto por Remmy Tessonneau, diretor do Instituto de Altos Estudos Cinematográficos de Paris, e por Mario Verdone, presidente do Comitê para o Intercâmbio Cultural da Itália.

Nesse ano, ainda, foi organizado no Instituto o seminário Documental, Ojo del mundo, Primera Semana Universitaria de Cine Documental Internacional. Além da exibição de 32 filmes, foram discutidos assuntos relativos à importância do documentário para o cinema contemporâneo e, em especial, para o argentino. Os textos utilizados expressavam a preocupação central dos realizadores do evento e o tipo de formação que defendiam: Cine Documental e Grierson y el Documental, os dois de J. A. Mahieu; Apuntes para una historia del documental, do Clube de Cinema de Santa Fé; Zavattini y la realidad, de Edgardo Pallero e Juan H. Croppi; Universidad y cine, de Fernando Birri; El Instituto de Cinematografía: toma de conciencia de una realidad, de 
Jorge Alberto Ferrando; Cómo trabajamos, de Juan F. Oliva; e Poesía y documento, de Alfredo Carrió.

No final da semana os integrantes encaminharam ao Instituto Nacional de Cinematografia resoluções que pediam regulamentação da Lei 62/57, que instituiu a obrigatoriedade de exibição de curta-metragens argentinos em todo o território nacional e a criação de uma Cinemateca Nacional e um Centro Experimental de Cinematografia. ${ }^{6}$

A partir de 1960, o organograma do Instituto foi modificado. O aluno poderia sair formado em: direção, direção de fotografia e direção de produção. O curso tinha duração de quatro anos; destes, três dedicados ao ciclo superior e um à especialização. O aluno podia ingressar no primeiro ano, caso já tivesse o nível médio, ou no curso preparatório.

A equipe operacional do Instituto de Cinematografia era composta pelo diretor, Fernando Birri; coordenador docente, Adelqui Camusso; chefe geral de oficina experimental, Edgardo Pallero; regente, Edmundo Blanco Boeri; administrador, Eduardo Fontanini; ajudante técnico, Carlos J. Gramaglia; laboratório fotográfico, Rodolfo Neder y Domingo Calabró; Departamento de Gramática e Biblioteca, Juan F. Oliva; Departamento de Compaginación, César Caprio; Oficinas de Meios Visuais, Ninfa Pajón; Editora Documento, Alfredo Ariel Carró; Preceptores, Selva Pajón e Régis Bartizzaghi; motorista, Pedro Micheli; mensageiro, Agustín Pelletti; ordenaza, Matilde Martín; e Delegado em Buenos Aires, Manuel Horacio Giménez.

Ao final de $1960^{7}$, foram aprovados 269 alunos. Considerando outros 39 reprovados, era um número bastante superior ao do início do curso. A filmografia estudada nos cursos sugeria a variedade e riqueza da temática e da estética abordada pelo Instituto. Os melhores exemplos são o filme Shunko, de Murúa-Abalos; os filmes franceses Correo nocturno, Mundos rivales e Paris 1900; filmes de Flaherty, de Charles Chaplin e do Neo-realismo italiano. Ainda foram exibidos e analisados 60 filmes primitivos, documentários e clássicos, italianos, franceses e norte-americanos, entre eles, Tempestad sobre Asia, Canción de Ceylan, Pacific 231, El desayuno del bebé, El asesinato del duque de Guisa, Un año después de la revolución de Cuba, Puente Alsina, La Ciudad del Oro, Octubre, Tiempo en el sol, La senda es larga, La salida de los obreros de la fábrica Lumiére, El regador regado, Berlín, sínfonia de una gran ciudad, Epopeya estudantil cubana, Viaje de la luna e filmes argentinos do início do século XX.

Mas a atuação do Instituto foi além do campo cinematográfico. Promoveu iniciativas em outras áreas, atuando como um centro catalisador para os artistas locais. 
Assim, em 1960, o Instituto realizou exposição de artes plásticas e conferências dos pintores Cézar Lópes Claro, C. Francisco Puccinelli, Enrique Estrada Bello, Fernando Espino, Pedro Logarzo e do escultor José Seflacek. Organizou mostra de filmes clássicos em parceria com a Universidade de Buenos Aires e com a Cinemateca SODRE, do Uruguai. Participou das Jornadas de Cultura Popular, organizadas pelas Secretarias de Cultura e Ação Social do Município de Santa Fé.

Em 1961, o organograma da Escola manteve-se praticamente o mesmo. Mas, através da resolução número 239, foi criado o Departamento de Publicações (Editorial Documento). Naquele ano, foi publicado Escuela documental inglesa, de Manuel Horacio Gimenez, e Historia del cortometraje argentino, de Agustín Mahieu. A editora começou a publicar uma revista sobre cinema, a Panorámica. O acervo da biblioteca, que já era de 500 exemplares, sobe para 700. Além de mostra de documentários japoneses, as atividades com artistas da região continuaram. ${ }^{8}$ Também foi realizada a Tercera Semana Universitaria de Cine Documental Internacional, dedicadas aos curtametragens produzidos pelo National Film Board do Canadá. Foram exibidos 36 filmes, publicado um catálogo com título Desarrollo del movimiento documental en Canadá e promovidos um ciclo de conferências de Juan F. Oliva, Mabel Itzcovich, Agustín Mahieu, Humberto Ríos e Fuad Quintan (Birri, 1964).

A essa altura o projeto do Instituto tomou proporções inesperadas. Jovens latinoamericanos correram em busca de vagas na ânsia de se tornarem cineastas. Entre estes podemos citar Maurice Capovilla e Vladimir Herzog ${ }^{9}$, do Brasil, Raúl Ruiz, do Chile e Dolly Pussi, da própria Argentina. Segundo ela, na década de 1960 "surgen de la Escuela Documental de Santa Fe realizadores como Juan Fernando Oliva, Gerardo Vallejo, Jorge Goldenberg" (Pussi, 1978, p.10).

O Instituto, ainda, gerou projetos fora da Argentina. No Brasil, sua influência apareceu em artigo de Maria do Rosário Caetano sobre o fotógrafo, produtor, professor e documentarista Thomaz Farkas, um dos pioneiros na realização de documentários no Brasil:

O cinema entraria, para valer, na vida do fotógrafo, quando ele conheceu o argentino Fernando Birri e os jovens hispano-americano e brasileiros (entre eles, Vladimir Herzog), que passaram pela Escola Documental de Santa Fé, na Argentina. Das discussões do grupo (integrado por Birri, Edgard Pallero, Maurice Capovilla, Manuel Giménez, Sérgio Muniz e Herzog) nasceu o desejo de realizar filmes sobre a realidade brasileira. (Caetano, 2003, p.3D) 
Foi o próprio Fernando Birri quem narrou a chegada de Vladimir Herzog e Maurice Capovilla à escola:

... um dia tocam a campainha do Instituto dois brasileiros que vinham com suas malinhas. Eles me perguntam: - 'É aqui que se ensina a fazer cinema?' - 'Sim, aqui se ensina a fazer cinema, mais ou menos, mas se ensina.' - 'Bom porque nós lemos sobre esta escola e queríamos ver se é possível ficar um pouco aqui, compartilhar'. Imagina para nós era maravilhoso que de repente dois companheiros brasileiros viessem a esta escola, não imaginávamos que a escola já pudesse ser conhecida no Brasil. Vieram para ficar uma semana e ficaram vários meses. (Almeida \& Muniz, 1997, p. 9)

Assim, o Instituto de Cinematografia de Santa Fé estava em franco crescimento e efervescência cultural quando, nos primeiros anos da década de1960, começou a sofrer boicotes e censura. Em sua Breve História del Documental, Dolly Pussi testemunha esta situação:

En 1962 el gobierno del presidente Guido decreta la prohibición y secuestro del negativo y copias del documental Los $40 \operatorname{cuartos}^{10}$, producido por el Instituto de Cinematografía de la Universidad del Litoral. El documental trata el problema de la vivienda y fue filmado en un "conventillo" (vivienda precaria en la que habitan numerosas familias) de la ciudad de Santa Fe con testimonios de los mismos habitantes y referencias en la columna sonora a la Carta de los Derechos Del Hombre de las Naciones Unidas. (Pussi, 1978, p. 14).

A última iniciativa de Fernando Birri, na Argentina, foi organizar o livro sobre o Instituto de Cinematografia, concluído na noite anterior de sua partida para o Brasil. Ele testemunhava:

Depois disso vem o momento terrível: 1963, em que nos damos conta que já não há mais espaço para nós, e que talvez a única maneira de preservar o Instituto de Cinematografia seja irmos embora. As circunstâncias políticas eram como o primeiro vendaval da ditadura que iria vir depois, para praticamente acabar com pessoas, filmes, livros, com a esperança de tantas gerações na Argentina. Neste momento decidimos sair da Argentina, junto a Edgardo Pallero, que foi o elemento determinante da Escola, sua companheira Dolly Pussi, Manoel Horacio Giménez, que depois ficou no Brasil como diretor, e com Carmen, que era minha companheira nesse momento. (Almeida \& Muniz, 1997, p.15)

Devido à repressão oficial, o Instituto de Cinematografia foi perdendo o seu caráter inovador e burocratizou-se. Mas teve um papel fundamental na renovação do cinema latino-americano. Peter Schumann afirma: 
En su escuela de cine documental, Fernando Birri supo conjugar la precaria tradición del cine crítico realista argentino (Ferreyra, Soffici, Torres Ríos, Carril) con las intenciones de los jóvenes renovadores, creando así el fundamento teórico y práctico, a partir del cual sería posible un trabajo cinematográfico más concreto y politizado. Además, Birri fue uno de los primeros - si no el primero en concebir la posibilidad de un cine latinoamericano más allá de los estrechos horizontes nacionales. (Schumann, 1987, p.25)

Mário Reis, analisando o cinema latino-americano, diz:

A fundação do Instituto de Cinematografia da Universidade do Litoral, no meio da década de 50, por Fernando Birri, com a realização dos filmes Tire dié (1956) e Los inundados (1961), com as mesmas propostas dos arautos brasileiros, levanos a admitir que Rio, 40 Graus (1955), juntamente com o primeiro documentário produzido pelo Instituto de Santa Fé, foram as obras que iniciaram um processo que fez surgir o Novo Cinema Latino-Americano, ganhando este uma notoriedade maior a partir da Resenha do Cinema Latino-Americano, em Gênova, na Itália, em janeiro de 1965, e a partir também do I Encontro de Cineastas Latino-Americanos em Viña del Mar, Chile, em 1967. (Reis, 1996, p.19)

É importante frisar que as relações do setor cinematográfico comercial com as universidades praticamente inexistiram no continente latino-americano até os anos 1950. As empresas mantinham o monopólio da produção, distribuição e exibição de filmes e muitas vezes usavam os sindicatos e órgãos oficiais para controlar o sistema. No México, por exemplo, os estudantes de cinema demoraram a poder realizar e exibir seus longa-metragens, como testemunha Jorge Fons, diretor mexicano, conhecido pelo filme $O$ Beco dos Milagres:

Sou da primeira geração da UNAM (Universidade Nacional Autônoma do México). Só que, quando concluí meu curso, não podia fazer filmes profissionais. Tínhamos formação universitária e só podíamos carregar cabos em filmes produzidos industrialmente. Havia normas rigorosíssimas do sindicato da atividade que impunham barreiras intransponíveis. Para não ficarmos parados, inventamos um artifício: filmes de episódios. Juntávamos três histórias e as filmávamos como se fossem curtas-metragens. Com o passar do tempo tomamos o sindicato e alteramos as regras. (Caetano, 1997, p.210)

Neste período surge uma nova mentalidade em relação à prática cinematográfica. Para os novos cineastas não era suficiente apenas realizar filmes prática usual até aquele momento -, mas acreditavam na necessidade do debate, da 
reflexão e de uma postura crítica em relação à estética cinematográfica e à sociedade. $\mathrm{O}$ aluno Juan F. Oliva, em artigo intitulado Urgencia de una Escuela Nacional de Cine (Birri, 1964, p.133), apontava a crise do cinema argentino naquele momento, mas refutava a idéia de que simplesmente o ressurgimento de sistemas de crédito (a Lei de Cinema 62/58) e o aparecimento de novos realizadores de curta-metragens, formados de modo empírico, poderiam elevar a qualidade do cinema argentino. Ele considerava fundamental a criação de uma escola nacional de cinema para sintetizar as experiências das escolas regionais existentes. ${ }^{11}$

É imprecisa a data de encerramento das atividades do Instituto de Cinematografia de Santa Fé. Em entrevista a Carmen Guarini para a revista Film, Birri testemunha que, sob a direção de Adelqui Camusso, vice-diretor à sua época, a escola teria ainda sobrevivido algum tempo após sua partida:

Supe por gente que vivía cerca de la escuela que, con la última dictadura militar, viu llegar uma noche dos camiones del ejército y se llevaron todo lo que nosotros, como hormiguitas, habíamos juntado: moviola, câmaras de cine, nuestros sueños ... Fue cuando se decidió que se acababa todo. (Guarini, 1995, p.15)

Freqüentaram o Instituto, segundo Fernando Birri, vários realizadores argentinos, entre eles: Juan Fernando Oliva, Edgardo Pallero, Enrique Urteaga, Rodolfo Neder, Manuel Horacio Giménez, Juana Elena Basso, Hugo Gola, Ninfa Pajón, Alfredo Carrió, Adelqui Camusso, Diego Bonacina, Dolly Pussi, Gerardo Vallejo, Jorge Goldenberg, César Caprio, O. Taverna, Oscar Souto, Raymundo Gleyzer e Jorge Cedrón.

Formados na síntese entre reflexão e prática, apesar das dificuldades e da falência da experiência de Santa Fé, dos festivais e dos congressos de cinema, esses novos diretores criaram as bases teóricas e estéticas do novo cinema latino americano que se configurou nos anos 1960 e se consolidou nos anos 1970.

\section{REFERÊNCIAS BIBLIOGRÁFICAS:}

ALMEIDA, Miguel de \& MUNIZ, Sérgio. Fernando Birri, cinema aberto: entrevista a Miguel de Almeida e Sérgio Muniz. São Paulo: Fundação Memorial da América Latina, 1997. 
AVELlAR, José Carlos. A Ponte Clandestina: Birri, Glauber, Solanas, Getino, García

Espinosa, Sanjinés, Aléa - Teorias de Cinema na América Latina. Rio de Janeiro/São Paulo: Edusp, 1995.

BIRRI, Fernando. La Escuela Documental de Santa Fe. Santa Fe: Editorial Documento del Instituto de cinematografia de la U.N.L., 1964.

DA-RIN, Silvio. Espelho Partido: tradição e transformação do documentário. Rio de Janeiro: Azougue Editorial, 2004.

CAETANO, Maria do Rosário. Cineastas Latino-Americanos: entrevistas e filmes. São Paulo: Estação Liberdade, 1997.

GUARINI, Carmen. Entrevista a Fernando Birri. Film, Buenos Aires, n.14, p.12-7, jun./jul, 1995.

PUSSI, Dolly. Breve Historia del Documental en la Argentina. Cine Cubano, Havana, n.84/85, p.32-3, 1978.

REIS, Mário Oliveira Reis. Gláuber Rocha e o pensamento americano (de Leopoldo Zea). Tese (Doutorado em História Social) - Faculdade de Filosofia, Ciências e Letras, Universidade de São Paulo, 1996.

SCHUMANN, Peter B. Historia del cine latinoamericano. Buenos Aires: Cine Libre/Lalgasa, 1987.

LIMA, Mônica Cristina Araújo. Cinema and social transformation: Santa Fé's cinematographic institute. História, São Paulo, v. 25, n. 2, p. 162-178, 2006.

Abstract: This paper discusses the implementation process of Santa Fé Cinematographic Institute at University of Litoral, in Argentina, concomitantly with a period of crisis in the Latin American cinematography. It identifies the influence of both Cinematography Experimental Centre of Rome - where its director and founder, Fernando Birri, had studied - and the School of English documentarists, directed by John Grierson. It also demonstrates the creativity of its participants in adapting international cinematographic proposals to Latin American societies and linking them to leftist cultural proposals of the 1950's. Moreover, it points out the singularity of its cinematographic production method and the relationship of the Institute with local communities.

Keywords: Latin America, Cinema, History.

Artigo recebido em 9/2006. Aprovado em 11/2006.

\section{NOTAS}


${ }^{*}$ Este artigo foi elaborado a partir do segundo capítulo de nossa tese, Fernando Birri: criação e resistência do cinema novo na América Latina, defendida, em março de 2005, no PROLAM/USP, sob orientação do prof. Dr. Afrânio Mendes Catani a quem agradecemos a cuidadosa orientação. Estendemos, ainda, nossos agradecimentos à Capes que, ao nos conceder bolsa pesquisa, viabilizou nosso projeto.

** Doutora pelo Programa de Pós-Graduação em Integração da América Latina (Prolam), da Universidade de São Paulo- USP. 05508-060, São Paulo, SP, Brasil.

${ }^{1}$ A Universidade Nacional do Litoral foi fundada pela reforma universitária de 1918. O Instituto Social, criado em 1928, foi decisivo para a fundação do Instituto de Cinematografia.

${ }^{2}$ A partir deste filme a produtora de Grierson, New Era Films, foi contratada pela estatal inglesa Empire Marketing Board (EMB) para realizar documentários para o governo inglês. Foram membros da produtora: Basil Wright, Evely Spiece, Arthur Elton, Edgar Anstey, Stuart Legg, Paul Rotha, Donald Taylor, Harry Watt, Marion Grierson, Robert Flaherty, o brasileiro Alberto Cavalcanti etc.

${ }^{3}$ A colaboração entre Drew e Leacock teve início em 1954. A Drew Associates formou-se em 1959 e dissolveu-se em 1963, quando Leacock abandonou a sociedade. Donn Pennebaker e Albert Maysles participaram do grupo por um período mais curto. A Drew Associates era financiada pelo grupo TimeLife e produziu mais de trinta filmes, entre eles: Primary (1960), Yankee No (1960), On the Pole (1961), Kenya (1961), Crisis (1962) e The Chair (1962) (Da-Rin, 2004, p.136).

${ }^{4}$ A partir de fotodocumentários foram surgindo os primeiros filmes do grupo e os manifestos conforme relação que se segue: Fotodocumentários de 1956: Tire dié, El conventillo, Edad Feliz, Nunzia, Mercado de Abasto, El Triángulo, Alto Verde, Un boliche, A la cola. Documentários de 1958: Tire dié, de Fernando Birri (1 ${ }^{\text {a }}$ versão, 59”). De 1959: La primera fundación de Buenos Aires, de Fernando Birri, La Inundación de Santa Fe, de Elena de Azcuénaga (10”); Retabillo de Perico, de César Cáprio (11"); $5^{\circ}$ dedo varo, de Enrique Arteaga (15"); El palenquero, de Hugo Abad (10"); López Claro, su pintura mural americana, de Juan F. Oliva (10”). De 1960: Luxación congénita de cadera, de Enrique Urteaga (18”); Opera El profesor Clarence Crafford, de Enrique Urteaga (5"); 50 años de la Escuela Industrial, de Carlos Gramaglia (15"); Buenos días, Buenos Aires, de Fernando Birri (20”); Tire dié (versão definitiva), de Fernando Birri (33”). De 1961: Los Ojos que oyen, de José Ayala (10”); Feria Franca, de Hercilia Marino (10"); Tierra para niños, de Hugo Abad (10”); Brucelosis, de César Caprio (10"); Los inundados, de Fernando Birri (primeiro longa-metragem de ficção). De 1962: La Pampa Gringa, de Fernando Birri (10"); El puente de papel, de Nelly Borroni (10"); Club de barrio, de Edgard van Isseidyk (10"); Los 40 cuartos, de Juan F. Oliva (20”); La cancha, de Juan F. Oliva (não consta o tempo).

${ }^{5} \mathrm{Um}$ dos realizadores do Festival de Cine Internacional Documental y Experimental del SODRE (Servicio Oficial de Difusión Radioeléctrica), desde 1954, em Montevidéu.

6 Assinavam as resoluções: "Fernando Birri, Diretor del Instituto de Cinematografía de la U.N.L.; Adelqui Camusso, Coordinador Docente de Instituto de Cinematografía de la U.N.L., Aldo Persano, Director del Departamento de Cinematografía de la Universidad Nacional de Buenos Aires; José Tapia, Jefe de la Sección Cine de la Dirección General de Cultura de la Nación; Jaime Potenze, crítico cinematográfico de la revista "Critério"; Víctor Iturralde, realizador de cortometraje; José Bullaude, Coordinador en la Mesa Redonda y profesor de Medios Audiovisuales del Instituto de Cinematografía de la U.N.L; Salvador Sammaritano, profesor de Historia del Cine del Instituto de Cinematografía de la U.N.L y miembro de la C. D. de la Federación Argentina de Cineclubes; José Agustín Mahieu, profesor de Crítiica Cinematográfica del Instituto de Cinematografía de la U.N.L. y miembro de la Asociación de Realizadores de Corto Metraje. Y adherían, sin excepción, todos dos representantes de los intereses culturales de la ciudad" (Birri, 1964, p.184-5).

${ }^{7}$ Em 1960 foi realizado o Ciclo Documento y Realismo Social, organizado por Manuel Horacio Giménez, com filmes de Alain Resnais, emprestados pela Embaixada da França: Van Gogh, Guernica, Gauguin, Toda la memoria del mundo e Noche y Niebla. Também foram exibidos longa-metragens inéditos cedidos pela Embaixada da Hungria, Dulce Ana, El casamiento de Ecser, El profesor Aníbal, todos de Zoltan Fabri. Entre os dias 19 e 26 de outubro de 1960, realizou-se a Segunda Semana Universitaria de Cine Documental Internacional, dedicada à Escola Documental Inglesa. Nestes dias foram exibidos 27 documentários produzidos, na Inglaterra e no Canadá, entre 1929 e 1959, por Grierson, Wrigth, Cavalcanti, Watt, Riley, Annakin, Dickson, Jennings, Anderson, Brenton, Keene, Clarke, Stanley, Jackson, Colin, Low, Wolf, Koening. Os documentários produzidos pelo Instituto foram exibidos nas cidades de Buenos Aires, Santa Fé, Rosário, Coronda, Paraná, Río Cuarto, Conceição do Uruguai, La Plata, Chivilcoy, Rafaela, San Cristóbal, Gobernador Crespo, San Justo e Mar del Plata.

${ }^{8}$ Muestra del Libro Santafesino, com exposição do escritor Julio A. Caminos e exposições dos artistas Richard Patausso, Jorge Planas Viader, Armando Godoy e Raúl Pecker. 


\footnotetext{
${ }^{9}$ Vladimir Herzog (1937-1975), autor do documentário Os Marimbás, de 1962, foi jornalista e diretor de redação da TV Cultura. Em 1973, foi preso e assassinado pela ditadura militar. Maurice Capovilla (1936), diretor de Bebel, Garota-Propaganda (1967), O Profeta da Fome (1970), O jogo da Vida (1976). Foi integrante do grupo de cineastas "Boca do Lixo" nos anos 70 e diretor do Instituto Dragão do Mar de Arte e Indústria Audiovisual do estado do Ceará (1996 a 1999).

${ }^{10}$ Los 40 cuartos foi a segunda pesquisa social filmada pelo grupo de Santa Fé, dirigida pelo aluno Juan F. Oliva, como tese de fim de curso. Depois de sua exibição, em 1962, na Mostra Anual de CurtaMetragem, organizada pela Direção Nacional de Cultura, o filme foi cassado pelo presidente Fernando Guido, em 30 de janeiro de 1963 (com base no decreto n. 4965/59).

${ }^{11}$ Existiam várias escolas de cinema espalhadas pela Argentina, mas nenhuma de caráter "nacional". Entre elas, o Instituto Cine-fotográfico e o Centro de Investigaciones de Medios Audiovisuales, da Universidade de Tucuman; o Instituto Cinematográfico, da Universidade de Buenos Aires; o Instituto de Cinematografia, da Universidade de La Plata; o Taller de Cine e a Asociación de Cine Experimental, de Buenos Aires; e o Instituto de Cinematografia, da Universidade Nacional do Litoral, de Santa Fé (Birri, 1964, p.134).
} 